\title{
Contralateral Upper Limb Weakness Following Botulinum Toxin A Injection for Poststroke Spasticity
}

\author{
Paresia do Membro Superior Contralateral Após \\ Infiltração de Toxina Botulínica A para Espasticidade \\ Pós-AVC
}

Alexandre CAMÕES-BARBOSA ${ }^{1}$, Ines Mendes RIBEIRO², Luisa MEDEIROS ${ }^{3}$

Acta Med Port 2020 Nov;33(11):761-764 - https://doi.org/10.20344/amp.11503

ABSTRACT

Botulinum toxin type A has been approved for spasticity management in poststroke patients. The adverse effects are generally of two types: those related to local injection; and those related to the systemic effects from spread of the toxin. Contralateral weakness after botulinum toxin $A$ treatment is a rarely reported adverse effect. We report the case of a 33-year-old female who had been receiving regular injections of incobotulinum toxin $A$ due to spasticity of the right limbs after a hemorrhagic stroke. A switch was made to abobotulinum toxin $A$ with an overall conversion ratio of 1:3.83. The patient presented contralateral upper limb paresis, especially of the deltoid muscle, in the second week post-injection. The electroneuromyography showed neuromuscular block due to botulinum toxin A. She recovered completely after eight months. A switch between different formulations of botulinum toxin type A should prompt caution when carrying out unit conversions. Distant side effects may appear, including paresis in the contralateral limbs.

Keywords: Botulinum Toxins, Type A/adverse effects; Muscle Weakness/etiology; Upper Extremity

\section{RESUMO}

A toxina botulínica A foi aprovada para o tratamento da espasticidade em doentes pós-AVC. Os efeitos adversos são geralmente de dois tipos: efeitos adversos relacionados com a administração local de toxina botulínica A; e efeitos adversos sistémicos relacionados com a difusão à distância da toxina. A paresia muscular dos membros contralaterais após tratamento com toxina botulínica $A$ é um efeito adverso raro. Descrevemos o caso de uma mulher de 33 anos de idade que recebia infiltrações regulares de toxina incobotulínica A por espasticidade dos membros direitos pós-AVC hemorrágico. Foi feita uma troca para toxina abobotulínica A com um factor de conversão global de 1:3,83. A doente apresentou parésia do membro superior contralateral, especialmente do músculo deltóide. A electroneuromiografia foi compatível com bloqueio neuromuscular devido a toxina botulínica $A$. Recuperou totalmente após oito meses. A troca entre diferentes formulações de toxina botulínica A deve exigir precaução na conversão das unidades. Efeitos adversos à distância podem surgir, incluindo parésia dos membros contralaterais.

Palavras-chave: Fraqueza Muscular/etiologia; Membros Superiores; Toxinas Botulínicas Tipo A/efeitos adversos

\section{INTRODUCTION}

Cardiovascular Botulinum toxin A (BoNT-A) has been approved for spasticity management. The most serious adverse effect is related to systemic spread, manifested by generalized weakness..$^{1,2}$ We report a case of contralateral upper limb weakness in a patient who received BoNT-A injection for poststroke spasticity.

\section{CASE REPORT}

A 33-year-old white female with a history of hemorrhagic stroke started a rehabilitation program that included BoNT-A in the right upper and lower limbs for spasticity management. Injections were performed at three-month intervals for five years, always with Incobotulinum toxin A (Inco/A) $400 \mathrm{U}$, except during the Tower study, ${ }^{3}$ when she received one $600 \mathrm{U}$ and one $800 \mathrm{U}$ injection. Due to unavailability of Inco/A in our hospital, a switch to Abobotulinum toxin $A$ had to be made. The new formulation injection was performed under ultrasonographic guidance. Approximately 10 days after injection, the caregivers noticed diminished muscle strength in the proximal left upper limb. The patient was assessed by her regular BoNT-A injector that found a paresis of the left shoulder flexors and abductors graded as 2 in the Medical Research Council scale; the left hemibody sensitivity, reflexes and tonus were normal, as well as muscle strength in other muscle groups. The magnetic resonance imaging did not show any findings suggestive of acute lesions. The electroencephalography showed normal baseline electrogenesis. A cervical spine MRI did not show any significant findings. The electroneuromyography (EMG) findings at day 21 and week 16 after injection are described in Table 1 and Table 2, respectively. Eighteen months after the patient's last BoNT-A injection, the caregivers reported full recovery of her left shoulder flexors and abductors strength. It was decided to resume treatment with a switch back to $450 \mathrm{U}$ of Inco/A. The patient has had good response to treatment, with adequate right hemi-body tonus control, and no further adverse effects.

1. Neurotoxin Clinic. Neurophysiology Unit. Centro Hospitalar Universitário de Lisboa Central. Lisboa. Portugal.

2. Physical Medicine and Rehabilitation Department. Hospital Prof. Doutor Fernando Fonseca. Amadora. Portugal.

3. Neurophysiology Unit. Centro Hospitalar de Lisboa Central. Lisboa. Portugal.

$\square$ Autor correspondente: Alexandre Camões-Barbosa. alexandre.camoes@gmail.com

Recebido: 03 de novembro de 2018 - Aceite: 26 de maio de 2019 | Copyright @ Ordem dos Médicos 2019 
Table 1 - Electroneuromyography at day 21 (third week post-toxin injection)

\begin{tabular}{|c|c|c|c|}
\hline \multirow{5}{*}{$\begin{array}{l}\text { Sensitivity } \\
\text { conduction study }\end{array}$} & \multicolumn{2}{|l|}{ Left median nerve (fingers 1 and 3 ) } & Normal \\
\hline & \multicolumn{2}{|l|}{ Left ulnar nerve } & Normal \\
\hline & \multicolumn{2}{|l|}{ Left radial nerve (superficial branch) } & Normal \\
\hline & \multicolumn{2}{|c|}{ Left lateral antebrachial cutaneous nerve } & Normal \\
\hline & \multicolumn{2}{|c|}{ Left medial antebrachial cutaneous nerve } & Normal \\
\hline \multirow[t]{5}{*}{$\begin{array}{l}\text { Motor conduction } \\
\text { study }\end{array}$} & Bilateral axillary nerve & \multicolumn{2}{|c|}{$\begin{array}{l}\text { Marked reduction of the left axillary nerve motor potential by comparison } \\
\text { to the right axillary nerve. Normal latencies on left and right sides, without } \\
\text { any significant asymmetries. }\end{array}$} \\
\hline & Bilateral musculocutaneous nerve & \multicolumn{2}{|c|}{ Normal, without any significant asymmetries. } \\
\hline & Left median nerve & \multicolumn{2}{|l|}{ Normal, including the $F$ waves. } \\
\hline & Left ulnar nerve & \multicolumn{2}{|c|}{ Normal, including the F waves. } \\
\hline & Left radial nerve & \multicolumn{2}{|c|}{ Normal, including the F waves. } \\
\hline \multirow[t]{9}{*}{$\begin{array}{l}\text { Repetitive } \\
\text { stimulation testing }\end{array}$} & \multirow[t]{7}{*}{$\begin{array}{l}\text { Low frequency stimulation }(3 \mathrm{~Hz}) \\
\text { (at rest) }\end{array}$} & Left deltoideus & $\begin{array}{l}45 \%-48 \% \text { decrement in amplitude; } \\
57 \%-64 \% \text { decrement in area }\end{array}$ \\
\hline & & Left anconeus & $\begin{array}{l}7 \%-8 \% \text { decrement in amplitude; } \\
9 \%-10 \% \text { decrement in area }\end{array}$ \\
\hline & & Right deltoideus & $\begin{array}{l}6 \%-13 \% \text { decrement in amplitude; } \\
14 \%-19 \% \text { decrement in area }\end{array}$ \\
\hline & & Right biceps brachii & No decrement \\
\hline & & Right trapezius & No decrement \\
\hline & & Right abductor digiti minimi & No decrement \\
\hline & & Abductor pollicis brevis & No decrement \\
\hline & \multirow{2}{*}{$\begin{array}{l}\text { High frequency stimulation }(20 \mathrm{~Hz} \\
\text { and } 50 \mathrm{~Hz} \text { ) }\end{array}$} & Left deltoid & No increment \\
\hline & & Left anconeus & No increment \\
\hline
\end{tabular}

Electromyography Fibrillations and/or positive waves in the left deltoideus and infra-spinatus muscles, with decreased activation, polyphasic PUM with small amplitude.

Very sparse fibrillations in the left brachoradialis and biceps brachii, with normal recruitment pattern.

Left pronator teres, flexor carpi radialis, triceps brachii, extensor indicis, first dorsal interosseous and cervical erector spinae muscles without pathological findings.

\section{DISCUSSION}

\section{Previously described case reports}

Muscle weakness contralateral to the injected side was found to be extremely rare in a systematic review. ${ }^{1}$ There are only three other case reports of patients who received BoNT for post-stroke spasticity and presented with contralateral upper extremity weakness. ${ }^{4,5}$ In the first described case, a 53-year-old woman received $800 \mathrm{U}$ and $500 \mathrm{U}$ of Ona/A, and developed contralateral weakness and fatigue two weeks after treatment. No electrophysiological testing was done in this case. In the following case, a 43-year-old woman received $700 \mathrm{U}$ of $\mathrm{Ona} / \mathrm{A}$, and three weeks later presented with contralateral upper extremity weakness. Upon electrophysiological testing, she revealed on slow $(3-\mathrm{Hz})$ repetitive nerve stimulation of the left axillary nerve a $23 \%$ decrement in amplitude. EMG revealed abnormal spontaneous activity and polyphasic motor unit potential (MUP) with reduced recruitment in the left deltoid, biceps brachii, and infraspinatus (the only muscles tested for comfort). On the 2-month follow up visit, she had improved, but was still recovering. In the third case, a 21-year-old woman, who had suffered a stroke when she was two years old, received $700 \mathrm{U}$ of Ona/A, and developed contralateral upper limb weakness six weeks posttreatment. A $2-\mathrm{Hz}$ repetitive stimulation of the spinal accessory nerve revealed a $16 \%$ decrease in amplitude. EMG showed mild abnormal spontaneous activity and small polyphasic motor unit potentials with reduced recruitment in the deltoids, biceps, infraspinatus and supraspinatus (the only muscles tested for patient comfort). In the 4-month follow up visit she had improved, but was still recovering. In the 5-month follow up visit she was reinjected and started to receive subsequent injections of $500 \mathrm{U}$ of Ona/A, without injection of any muscle proximal to the elbow, and did not present further contralateral upper limb weakness.

Table 2 - Electroneuromyography at week 16th post-toxin injection

\begin{tabular}{llll}
\hline $\begin{array}{l}\text { Repetitive } \\
\text { stimulation testing }\end{array}$ & Low frequency stimulation $(3 \mathrm{~Hz})$ & Left deltoideus & $20 \%-27 \%$ decrement in amplitude; \\
& (at rest) & Left anconeus & $26 \%-29 \%$ decrement in area \\
& & Right deltoideus & No decrement \\
& & No decrement \\
\hline
\end{tabular}




\section{Similarities to our case report}

In accordance with these three case reports, our patient was also female and presented with contralateral upper limb weakness (there was no weakness noted in the lower limb) in the second week following treatment. Electrophysiological testing was suggestive of dysfunction at the level of the motor endplate, showing, in slow $(3-\mathrm{Hz})$ repetitive stimulation, a $45 \%-48 \%$ decrease in amplitude. The EMG findings of fibrillations and/or positive waves in the left deltoideus and infraspinatus muscles, with decreased recruitment, and small amplitude polyphasic MUPs have been described in botulism and are attributed to severe blockade of the neuromuscular junction. ${ }^{6}$

\section{Adverse events}

Systemic adverse effects reported after BoNT limb muscles injection include muscle weakness distant to the injection site, dysphagia, and dry mouth, among others. ${ }^{1}$ Absorption of free BoNT may occur through the capillary system. It is also possible that a combination of vascular and neural spread occurs. Limited evidence exists of retrograde axonal spread in humans. Most evidence of this mechanism is derived from animal studies, ${ }^{1}$ and it is still unclear if the transported BoNT remains enzymatically active. ${ }^{7,8}$ Taking all into account, we believe that the most probable cause for contralateral weakness in our patient was 'hematogenous spread'. Although BoNT can travel through muscle fascia, as hypothesized by Thomas and Simpson, ${ }^{5}$ we do not believe this to be the most plausible explanation, because: (1) the most proximal muscle injected in our patient was the biceps brachii (injected at half distance between the shoulder and the elbow); (2) there was no weakness in the muscles present in the hypothetic subcutaneous or transfascial trajectory of BoNT until it reached contralateral deltoids (namely, there was no weakness of the coracobrachialis or any of the pectoralis muscles; (3) the ipsilateral deltoid muscle showed a smaller decrease in amplitude than the contralateral deltoid to low-frequency stimulation which would probably not have happened if we consider local diffusion gradients (higher proximal to the injection site); (4) if it was not osmotically but mechanically induced movement, it should not have affected the contralateral upper limb, because the trajectory that would have to be made was against gravity. Our hypothesis is that saturation of BoNT receptors occurred in one or more of the injection sites, and that unbounded BoNT was washed away from that/those regions by the circulatory system, specially the capillary system. Why did it affect predominantly the contralateral deltoid muscle (and not other muscles, such as the orbicularis oculi or swallowing muscles) we do not know and it is a question that could be addressed in further studies. Perhaps it can have something to do with the deltoid muscle having a high blood flow, ${ }^{9}$ which could increase the probability of circulating unbound BoNT binding to the motor endplates at that anatomical region (increased number of unbounded BoNT molecules present at that site per unit of time) and not binding sufficiently in other muscles in order to produce clinical symptoms.

\section{Dose equivalence}

The conversion ratio between Ona/A and $A b o / A$ is still debated. Even if the most commonly quoted conversion ratios are $1: 3$ or $1: 4,{ }^{10}$ they range from $1: 1^{11}$; to as high as $1: 11 .{ }^{12}$ However, in studies where the conversion ratio is higher than 1:3, Abo/A showed higher efficacy and longer duration of action compared to Ona/A, but with more adverse events. ${ }^{13}$ In our case case the mean conversion factor of Inco:Abo was 1:3.83, which could have led to systemic BoNT diffusion.

\section{CONCLUSION}

Weakness of contralateral muscles to the injected side with BoNT is extremely rare and reported in very few studies. Physicians should be aware that a number of factors influence efficacy, diffusion and spread. In our patient, a global conversion ratio of 1:3.83 was used, which seemed to be the determinant factor that caused system spread of BoNT.

\section{PROTECTION OF HUMANS AND ANIMALS}

The authors declare that the procedures were followed according to the regulations established by the Clinical Research and Ethics Committee and to the Helsinki Declaration of the World Medical Association.

\section{DATA CONFIDENTIALITY}

The authors declare having followed the protocols in use at their working center regarding patients' data publication.

\section{PATIENT CONSENT}

Obtained.

\section{CONFLICTS OF INTEREST}

All authors report no conflict of interest.

\section{FUNDING SOURCES}

This research received no specific grant from any funding agency in the public, commercial, or not-for-profit sectors.

\section{REFERENCES}

1. Phadke CP, Balasubramanian CK, Holz A, Davidson C, Ismail F, Boulias C. Adverse clinical effects of botulinum toxin intramuscular injections for spasticity. Can J Neurol Sci. 2016;43:298-310.

2. Crowner B, Torres-Russotto D, Carter A, Racette B. Systemic weakness after therapeutic injections of botulinum toxin a: a case series and review of the literature. Clin Neuropharmacol. 2010;33:243-7.

3. Wissel J, Bensmail D, Ferreira JJ, Molteni F, Satkunam L, Moraleda S, et al. Safety and efficacy of incobotulinumtoxinA doses up to $800 \mathrm{U}$ in 
limb spasticity: The TOWER study. Neurology. 2017;88:1321-8.

4. Varghese-Kroll E, Elovic EP. Contralateral weakness and fatigue after high-dose botulinum toxin injection for management of poststroke spasticity. Am J Phys Med Rehabil. 2009;88:495-9.

5. Thomas AM, Simpson DM. Contralateral weakness following botulinum toxin for poststroke spasticity. Muscle Nerve. 2012;46:443-8.

6. Maselli R, Bakshi N. Botulism. Muscle Nerve. 2000;23:1137-44

7. Matak I, Bach-Rojecky L, Filipovi B, Lackovi AZ. Behavioral and immunohistochemical evidence for central antinociceptive activity of botulinum toxin a. Neuroscience. 2011;186:201-7.

8. Matak I, Riederer P, Lacković Z. Botulinum toxin's axonal transport from periphery to the spinal cord. Neurochem Int. 2012;61:236-9.

9. Mishra SK, Haining JL. Measurement of local skeletal muscle blood flow in normal humans by hydrogen clearance. Muscle Nerve. 1980;3:289
92.

10. Aoki KR, Ranoux D, Wissel J. Using translational medicine to understand clinical differences between botulinum toxin formulations. Eur J Neurol. 2006;13:10-9.

11. Wohlfarth K, Göschel H, Frevert J, Dengler R, Bigalke H. Botulinum A toxins: inits versus units. Naunyn Schmiedebergs Arch Pharmacol. 1997;355:335-40.

12. Marchetti A, Magar R, Findley L, Larsen JP, Pirtosek Z, Růzicka E, et al. Retrospective evaluation of the dose of dysport and BOTOX in the management of cervical dystonia and blepharospasm. Mov Disord. 2005;20:937-44.

13. Scaglione F. Conversion ratio between botox $(R)$, dysport $(R)$, and xeomin(R) in clinical practice. Toxins. 2016;8:65. 